\title{
Evaluation of the Think First head and spinal cord injury prevention program
}

\author{
Mona Wright, Frederick P Rivara, Deborah Ferse
}

\begin{abstract}
Objective-Evaluation of the impact of the Think First head and spinal cord injury prevention program on knowledge, attitudes, and behavior of 11-15 year old students toward injury risks and preventive strategies.
\end{abstract}

Setting-Three junior high and three senior high schools in rural and urban areas of Washington state.

Methods-Questionnaire survey before intervention, two weeks and three months after intervention to assess knowledge, attitude, and self reported behavior change. Observations of students as they left school property to determine bicycle helmet and seat belt use.

Results-Little impact on attitudes and no consistent change in knowledge or self reported behaviors. Too few students rode bicycles to accurately assess helmet use; no consistent change in seat belt use.

Conclusion-The Think First program appears to have little impact on changes in knowledge, self reported behavior, or observed behavior. Other strategies to decrease injuries in adolescents may be more successful.

(Injury Prevention 1995; 1: 81-85)

Keywords: head injury, spinal cord injury, program evaluation, education.

Traumatic brain and spinal cord injury are a major health problem among children and adolescents in the United States. Each year, approximately 7000 individuals under the age of 19 die from traumatic brain injury ${ }^{1}$ and over 3000 suffer spinal cord injuries. ${ }^{2}$ Even more important is the tremendous impact of these injuries expressed as morbidity, functional disability, or psychological impairment. ${ }^{3}$ These injuries also have a lifelong impact on their victims' families, schools, and communities. ${ }^{4}$ Across all age groups, the total lifetime costs for survivors of acute traumatic brain injury alone were estimated to be $\$ 24$ billion in $1985 . .^{5}$ In economic analyses, some individuals consider severe traumatic brain injury and spinal cord injury to be fates worse than death. ${ }^{6}$ The ability of medical care to reverse the consequences of these injuries is limited; consequently, the major strategy to decrease the impact of traumatic brain injury and spinal cord injury must be through primary prevention.

One of the methods that has been developed to prevent these injuries among youth is a school based educational program, Think First. Now being implemented in at least 43 states, the program combines factual information with a hard hitting emotional appeal to change adolescents' knowledge, attitudes, and ultimately, behavior. ${ }^{7}$ The hope is that through a combination of reduction in risk taking behavior and an increase in the use of safe behaviors and protective devices, traumatic brain injury and spinal cord injury would be reduced.

There are now over 100 active Think First programs in the country to which over 1.5 million school aged students have been exposed. ${ }^{8}$ Because of this widespread use, both in our own state and others, we undertook a formal evaluation of this program.

\section{Methods}

\section{PROGRAM DESCRIPTION}

Think First is conducted in middle schools and high schools by project staff. It is usually implemented in an all-school assembly format in the school gymnasium or auditorium. The hour long program was designed to provide students with basic information about the frequency and causes of traumatic brain injury and spinal cord injury, and is based on the health belief model. ${ }^{9}$ It consists of a short film about the consequences of traumatic brain injury and spinal cord injury, a lecture by a staff speaker who provides information on the frequency and causes of these injuries, a victim of traumatic brain injury or spinal cord injury testifying to the impact of the injury on his or her life, followed by a question and answer session. Specific preventive actions discussed include use of seat belts, motorcycle helmets, bike helmets, avoidance of drugs and alcohol while driving or participating in sports activities, and checking for water depth when swimming or diving.

\section{EVALUATION}

The evaluation consisted of before and after test questionnaires as well as direct observations of seat belt and bike helmet use. Schools selected were those that were given the Think First program early enough in the school year to allow us to conduct evaluations two weeks and three months after the intervention and before the school year ended. A convenience sample of three middle schools and three high schools was chosen for the evaluation to include rural (2), urban (3), and suburban (1) schools. The schools ranged in size from 285 students in one of the rural middle schools to 1128 in one of the urban middle schools. 
A questionnaire was developed to measure knowledge, attitudes, and reported behaviors based on the objectives of the Think First program, that is, we attempted to measure what the program was designed to change. The questionnaire was pilot tested and revised. It consisted of 39 questions, divided into knowledge, attitude, and behavior areas. Questions were either answered as multiple choice, true-false or on a Likert-type scale. For middle school use, questions concerning driving were omitted.

The questionnaire was administered by classroom teachers before the Think First group assembly, and at two weeks and three months after. We believed that if any effect occurred, it should be measurable two weeks after the assembly. If the effect was meaningful, it would need to persist for some period of time, for example at least three months. The questionnaire was anonymous, and individuals responses were not linked to either observations or. scores on prior questionnaires.

To test whether repeated administration of the questionnaire would itself constitute an intervention, students at a control high school were asked to complete a shortened version of the survey twice, two weeks apart. The control high school was a small (230 student) rural school, which agreed to have students take the questionnaire twice without an intervention in between. Students in this school were given the Think First program the day after the second set of data collection. This control school allowed us to assess whether completing the questionnaire itself could alone lead to changes in the responses.

To obtain information on the impact of the program on behavior change, use of seat belts

Table 1 Characteristics of participating students in the Think First evaluation; results are number $(\%)$ *

\begin{tabular}{|c|c|c|c|}
\hline & \multirow{2}{*}{$\begin{array}{l}\text { Before } \\
\text { assembly }\end{array}$} & \multicolumn{2}{|c|}{ After assembly } \\
\hline & & 2 weeks & 3 months \\
\hline \multicolumn{4}{|c|}{ Junior high school $\dagger$} \\
\hline Grade level & & & $71(36)$ \\
\hline 6th & $123(34)$ & $110(32)$ & $39(20)$ \\
\hline 7th & $130(36)$ & $129(37)$ & 76 (39) \\
\hline 8th & $102(29)$ & $105(30)$ & $9(5)$ \\
\hline 9th & $3(1)$ & $3(1)$ & \\
\hline \multicolumn{4}{|l|}{ Sex } \\
\hline Female & $174(49)$ & $171(50)$ & $99(52)$ \\
\hline \multicolumn{4}{|l|}{ Age } \\
\hline 11 & $56(15)$ & $41(12)$ & $24(12)$ \\
\hline 12 & $136(38)$ & $114(33)$ & $53(27)$ \\
\hline 13 & $117(33)$ & $117(33)$ & $57(29)$ \\
\hline 14 & $42(12)$ & $60(17)$ & $41(21)$ \\
\hline 15 & $7(2)$ & $14(4)$ & $19(10)$ \\
\hline Total (3 schools) & 372 & 360 & 202 \\
\hline \multicolumn{4}{|l|}{$\begin{array}{l}\text { High school } \\
\text { Grade level }\end{array}$} \\
\hline $\begin{array}{l}\text { Grade level } \\
\text { 9th }\end{array}$ & & & \\
\hline 10th & $\begin{array}{r}165(57) \\
57(20)\end{array}$ & $\begin{array}{r}123(51) \\
49(20)\end{array}$ & $\begin{array}{c}41(93) \\
1(2)\end{array}$ \\
\hline 11 th & $24(8)$ & $26(11)$ & $1(2)$ \\
\hline 12th & $42(15)$ & $42(18)$ & $1(2)$ \\
\hline \multicolumn{4}{|l|}{ Sex } \\
\hline Female & $150(52)$ & $134(56)$ & $22(50)$ \\
\hline \multicolumn{2}{|l|}{ Age } & $105(44)$ & \\
\hline 13 & $2(1)$ & $4(2)$ & \\
\hline 14 & 94 (33) & $51(21)$ & $12(27)$ \\
\hline 15 & $91(32)$ & $92(38)$ & $22(50)$ \\
\hline 16 & $43(15)$ & 38 (16) & $7(16)$ \\
\hline 17 & 39 (13) & $31(13)$ & $1(2)$ \\
\hline $\begin{array}{c}18 \\
\text { Total (3 schools) }\end{array}$ & $19(6)$ & $24(0)$ & $1(2)$ \\
\hline Total (3 schools) & 291 & 249 & 46 \\
\hline
\end{tabular}

Rounding may have resulted in per cents not adding to 100 . †Missing values: grade level 34 sex 40 , age 36 , race 53 . $\ddagger$ Missing values: grade level 12 , sex 16 , age 12 , race 6 . and bike helmets was observed at one middle school, one high school, and the control school. These observations were made as the students were leaving school property at the end of the school day.

\section{ANALYSIS}

An attitude score was constructed for each student by adding the responses on the Likerttype attitude questions, so that the highest score reflected the safest attitude. There were six attitude questions for middle school students, eight for high school students, and five for the control school. Likewise, a knowledge score was computed for each student as a summary of all knowledge questions. The number of questions in this summary score was 22 for the middle school, 22 for the high school, and eight for the control school.

Mean scores were calculated and differences between before and after tests were analyzed using Student's $t$ test.

\section{Results}

There were a total of 663 questionnaires completed before assembly ( 372 middle school students and 291 high school students). Altogether 609 (360 middle school and 249 high school) were completed at the two week follow up and 248 (202 middle school and 46 high school) at the three month follow up. The three month follow up assessment was only completed in three (two middle and one high) schools. The control school had 78 students complete the measure at both assessments.

There was good representation of all grades, with the exception of fewer students in the 11th and 12 grades completing questionnaires at any of the times (tables 1 and 2). The number of male and female students was similar, and the majority were white.

There were no significant changes in the attitude scores between baseline and the two follow up assessments in the intervention schools, nor between the two assessments in the control school (table 3). We did find some significant differences between the before test and follow up mean values for the knowledge score, although the differences were small (table 4). The middle school students showed a

Table 2 Charactistics of students in the control school; results are number $(\%)^{\star}$

\begin{tabular}{lll}
\hline & $\begin{array}{l}2 \text { weeks before } \\
\text { assembly }\end{array}$ & $\begin{array}{l}1 \text { day before } \\
\text { assembly }\end{array}$ \\
\hline $\begin{array}{l}\text { Grade level } \dagger \\
\text { 9th } \\
\text { 10th }\end{array}$ & 0 & $18(24)$ \\
11 th & $25(32)$ & $21(29)$ \\
12th & $30(39)$ & $13(18)$ \\
Sex & $22(29)$ & $21(29)$ \\
Female & & \\
Male & $43(56)$ & $36(50)$ \\
Age† & $34(44)$ & $36(50)$ \\
15 & & \\
16 & $3(3)$ & $11(15)$ \\
17 & $18(23)$ & $12(16)$ \\
18 & $30(39)$ & $26(36)$ \\
Total (1 school) & $27(35)$ & $24(33)$ \\
\end{tabular}

* Rounding may have resulted in per cents not adding to 100 †Missing values: grade level 6 , sex 7, age 6 . 
significant increase in knowledge scores at both two weeks and three months after assembly compared with baseline values, reflecting an increase in one or two questions answered correctly out of the 22 included in the score. There was no significant increase in knowledge

Table 3 Attitude scores by school assessment period; results are mean (SD)

\begin{tabular}{|c|c|c|c|c|c|}
\hline & $\begin{array}{l}\text { Before } \\
\text { assembly }\end{array}$ & $\begin{array}{l}2 \text { weeks } \\
\text { after } \\
\text { assembly }\end{array}$ & p Value ${ }^{\star}$ & $\begin{array}{l}3 \text { months } \\
\text { after } \\
\text { assembly }\end{array}$ & p Value \\
\hline $\begin{array}{l}\text { Junior high school } \\
\text { (highest possible } \\
\text { score }=6.0 \text { ) }\end{array}$ & $3.7(1.3)$ & $3.7(1.4)$ & NS & $3.8(1.5)$ & NS \\
\hline $\begin{array}{l}\text { High school } \\
\text { (highest possible } \\
\text { score }=8 \cdot 0 \text { ) }\end{array}$ & $5 \cdot 3(1.4)$ & $5 \cdot 2(1 \cdot 7)$ & NS & $4.9(2.0)$ & NS \\
\hline $\begin{array}{l}\text { Control school } \dagger \\
\text { (highest possible } \\
\text { score }=5 \cdot 0 \text { ) }\end{array}$ & $3.4(1 \cdot 2)$ & $3.3(1.4)$ & NS & & \\
\hline
\end{tabular}

NS = not significant. ${ }^{\star}$ Significance of difference from baseline. †Control school survey intervals were 2 weeks before and 1 day before the Think First assembly.

Table 4 Knowledge scores by school assessment period; results are mean (SD)

\begin{tabular}{|c|c|c|c|c|c|}
\hline & $\begin{array}{l}\text { Before } \\
\text { assembly }\end{array}$ & $\begin{array}{l}2 \text { weeks } \\
\text { after } \\
\text { assembly }\end{array}$ & $p$ Value $^{\star}$ & $\begin{array}{l}3 \text { months } \\
\text { after } \\
\text { assembly }\end{array}$ & p Value \\
\hline $\begin{array}{l}\text { Junior high school } \\
\text { (highest possible } \\
\text { score }=22 \text { ) }\end{array}$ & $15.0(3.0)$ & $16.9(3.8)$ & NS & $16 \cdot 2(4 \cdot 1)$ & $<0.05$ \\
\hline $\begin{array}{l}\text { High school } \\
\text { (highest possible } \\
\text { score }=22 \text { ) }\end{array}$ & $16 \cdot 1(2 \cdot 9)$ & $16.6(3.2)$ & NS & $14 \cdot 6(4 \cdot 2)$ & $<0.05$ \\
\hline $\begin{array}{l}\text { Control school } \dagger \\
\text { (highest possible } \\
\text { score }=\mathbf{5} \cdot 0 \text { ) }\end{array}$ & $4.6(1.4)$ & $4.6(1.3)$ & NS & & \\
\hline
\end{tabular}

NS = not significant. ${ }^{\star}$ Significance of difference from baseline. +Control school survey intervals were 2 weeks before and 1 day before the Think First assembly.

Table 5 Selected reported behaviors (affirmative responses); results are number (\%)

\begin{tabular}{|c|c|c|c|c|c|}
\hline & $\begin{array}{l}\text { Before } \\
\text { assembly }\end{array}$ & $\begin{array}{l}2 \text { weeks } \\
\text { after } \\
\text { assembly }\end{array}$ & p Value ${ }^{\star}$ & $\begin{array}{l}3 \text { months } \\
\text { after } \\
\text { assembly }\end{array}$ & p Value \\
\hline $\begin{array}{l}\text { Do you wear a helmet } \\
\text { Junior high school } \\
\text { High school } \\
\text { Control school } \dagger\end{array}$ & $\begin{array}{l}\text { en riding a b } \\
346(27 \cdot 5) \\
252(14 \cdot 7) \\
59(0)\end{array}$ & $\begin{array}{l}\text { cle? } \\
341(23 \cdot 2) \\
208(20 \cdot 2) \\
58(5 \cdot 2)\end{array}$ & $\begin{array}{l}\text { NS } \\
\text { NS } \\
\text { NS }\end{array}$ & $\begin{array}{r}188(12 \cdot 2) \\
41(24 \cdot 4)\end{array}$ & $\begin{array}{l}<0.001 \\
\text { NS }\end{array}$ \\
\hline $\begin{array}{l}\text { Do you wear a helmet } \\
\text { Junior high school } \\
\text { High school } \\
\text { Control school } \dagger\end{array}$ & $\begin{array}{l}\text { en riding a m } \\
215(67 \cdot 9 \\
159(64 \cdot 8) \\
55(67 \cdot 3)\end{array}$ & $\begin{array}{l}\text { orcycle? } \\
221(57 \cdot 5) \\
127(61 \cdot 1) \\
55(52 \cdot 7)\end{array}$ & $\begin{array}{l}\text { NS } \\
\text { NS } \\
\text { NS }\end{array}$ & $\begin{array}{r}142(66.2) \\
13(50.0)\end{array}$ & $\begin{array}{l}\text { NS } \\
\text { NS }\end{array}$ \\
\hline $\begin{array}{l}\text { Do you wear a seat bel } \\
\text { Junior high school } \\
\text { High school } \\
\text { Control school } \dagger\end{array}$ & $\begin{array}{c}\text { hen riding as } \\
368(80 \cdot 4) \\
286(80 \cdot 1) \\
78(64 \cdot 1)\end{array}$ & $\begin{array}{r}\text { passenger? } \\
355(78 \cdot 0) \\
244(80 \cdot 3) \\
76(63 \cdot 2)\end{array}$ & $\begin{array}{l}\text { NS } \\
\text { NS } \\
\text { NS }\end{array}$ & $\begin{array}{r}201(68 \cdot 7) \\
44(72 \cdot 7)\end{array}$ & $\begin{array}{l}\text { NS } \\
\text { NS }\end{array}$ \\
\hline $\begin{array}{l}\text { Do you wear a seat belt } \\
\text { High school } \\
\text { Control school } \dagger\end{array}$ & $\begin{array}{c}\text { hen driving? } \\
197(80 \cdot 7) \\
75(65 \cdot 3)\end{array}$ & $\begin{array}{r}172(79 \cdot 1) \\
70(67 \cdot 1)\end{array}$ & $\begin{array}{l}\text { NS } \\
\text { NS }\end{array}$ & $32(68 \cdot 8)$ & NS \\
\hline $\begin{array}{l}\text { Did you wear a seat be } \\
\text { Junior high school } \\
\text { High school } \\
\text { Control school } \dagger\end{array}$ & $\begin{array}{l}\text { the LAST tim } \\
368(29 \cdot 6) \\
285(32 \cdot 3) \\
77(40 \cdot 3)\end{array}$ & $\begin{array}{l}\text { you rode in } \\
3 \cdot 7(33 \cdot 1) \\
241(29 \cdot 1) \\
72(44 \cdot 4)\end{array}$ & $\begin{array}{l}\text { ar? } \\
\text { NS } \\
\text { NS } \\
\text { NS }\end{array}$ & $\begin{array}{r}201(40 \cdot 8) \\
41(31 \cdot 7)\end{array}$ & $\begin{array}{l}0.01 \\
\text { NS }\end{array}$ \\
\hline $\begin{array}{l}\text { Did you check the dept } \\
\text { Junior high school } \\
\text { High school } \\
\text { Control school } \dagger\end{array}$ & $\begin{array}{l}\text { of water befor } \\
339(56 \cdot 6) \\
220(65 \cdot 0) \\
71(49 \cdot 3)\end{array}$ & $\begin{array}{l}\text { diving? } \\
329(57 \cdot 8) \\
203(57 \cdot 1) \\
67(46 \cdot 3)\end{array}$ & $\begin{array}{l}\text { NS } \\
\text { NS } \\
\text { NS }\end{array}$ & $\begin{array}{r}184(52.2) \\
38(55.3)\end{array}$ & $\begin{array}{l}\text { NS } \\
\text { NS }\end{array}$ \\
\hline $\begin{array}{l}\text { Do you look for subme } \\
\text { Junior high school } \\
\text { High school } \\
\text { Control school } \dagger\end{array}$ & $\begin{array}{l}\text { d objects bef } \\
332(63 \cdot 0) \\
217(67 \cdot 3) \\
70(70 \cdot 0)\end{array}$ & $\begin{array}{l}\text { e diving? } \\
320(68 \cdot 1) \\
204(63 \cdot 7) \\
65(61 \cdot 0)\end{array}$ & $\begin{array}{l}\text { NS } \\
0 \cdot 001 \\
\text { NS }\end{array}$ & $\begin{array}{r}184(60.9) \\
36(69.4)\end{array}$ & $\begin{array}{l}\text { NS } \\
\text { NS }\end{array}$ \\
\hline $\begin{array}{l}\text { Do you use drugs or al } \\
\text { Junior high school } \\
\text { High school } \\
\text { Control school } \dagger\end{array}$ & $\begin{array}{l}\text { hol before dri } \\
298(7 \cdot 4) \\
208(3 \cdot 4) \\
67(13 \cdot 4)\end{array}$ & $\begin{array}{l}18 ? \\
291(5 \cdot 8) \\
186(8 \cdot 1) \\
66(18 \cdot 2)\end{array}$ & $\begin{array}{l}\text { NS } \\
\text { NS } \\
\text { NS }\end{array}$ & $\begin{array}{r}159(51 \cdot 1) \\
33(15 \cdot 2)\end{array}$ & $\begin{array}{l}0.01 \\
0.01\end{array}$ \\
\hline $\begin{array}{l}\text { If you were intoxicated } \\
\text { High school } \\
\text { Control school } \dagger\end{array}$ & $\begin{array}{c}\text { ould you let } \\
193(83.4) \\
69(75 \cdot 4)\end{array}$ & $\begin{array}{l}\text { riend drive? } \\
167(82 \cdot 0) \\
70(77 \cdot 1)\end{array}$ & $\begin{array}{l}\text { NS } \\
\text { NS }\end{array}$ & $34(76 \cdot 5)$ & NS \\
\hline $\begin{array}{l}\text { Would you let an intoxi } \\
\text { High school } \\
\text { Control school } \dagger\end{array}$ & $\begin{array}{l}\text { ted friend dri } \\
243(6 \cdot 2) \\
74(10 \cdot 8)\end{array}$ & $\begin{array}{l}213(8 \cdot 0) \\
74(13 \cdot 5)\end{array}$ & $\begin{array}{l}\text { NS } \\
\text { NS }\end{array}$ & $39(17 \cdot 9)$ & $\begin{array}{l}0.02 \\
\text { NS }\end{array}$ \\
\hline $\begin{array}{l}\text { Have you ridden with a } \\
\text { High school } \\
\text { Control school } \dagger\end{array}$ & $\begin{array}{l}\text { intoxicated dr } \\
368(17.9) \\
283(28.3)\end{array}$ & $\begin{array}{l}\text { er in the pas } \\
354(22 \cdot 9) \\
238(28 \cdot 2)\end{array}$ & $\begin{array}{l}\text { ionth? } \\
\text { NS } \\
\text { NS }\end{array}$ & $\begin{array}{r}199(26 \cdot 6) \\
43(39 \cdot 5)\end{array}$ & $\begin{array}{l}0.02 \\
\text { NS }\end{array}$ \\
\hline
\end{tabular}

NS = not significant. ${ }^{*}$ Significance of difference from baseline. +Control school survey intervals were 2 weeks before and 1 day before the Think First assembly. scores for the high school students two weeks after the assembly, and a small, but statistically significant, decrease in scores at the three month follow up. No differences were found between the two assessments in the control school scores on the knowledge summary score.

Selected, self reported behaviors are shown in table 5. There appeared to be little consistent pattern in changes in these behaviors. Some changes were larger at three months than two weeks, and the changes were in both directions, with some behaviors increasing and others decreasing. Overall, the changes from baseline were small. Of note, however, is that eight of the nine statistically significant self reported behavior changes were in the direction of more unsafe behavior after the Think First program.

Few students rode bicycles to school, limiting the number of observations of helmet use. Of the 22 students observed riding bikes in all the observations combined, only one wore a helmet (table 6). Similarly, there appeared to be no impact on seat belt use (table 6), although there was a small, significant increase at two weeks in the middle school, but a nonsignificant decline to lower than baseline at three months. Both of the follow up observations of the high school students revealed lower seat belt use than at baseline, although the change was not statistically significant. There did not appear to be any change of belt use at the control site.

\section{Discussion}

Given scarce resources, injury prevention programs should be rigorously evaluated for their impact on prevention of injuries to children and adolescents. ${ }^{1011}$ However, such evaluations often pose serious methodological difficulties. While traumatic brain injury and spinal cord injury are important problems, they are nevertheless relatively rare events. For example, Kraus et al found that the rate of brain injury requiring hospital care was only 294.5/100 000 for adolescents 15-19 years of age. ${ }^{1}$ To see a significant impact on traumatic brain injury rates would therefore require a very large number of students.

One alternative is to examine the impact of the program on changes in knowledge, attitudes, and behavior. Changes in knowledge and attitudes, however, do not necessarily translate into changes in injury behavior ${ }^{10}$ For example, Project Burn Prevention showed that changes in knowledge and attitudes with regard to fire and burn prevention could be achieved in certain groups with a school community campaign. ${ }^{12}$ However, these changes had no impact on actual prevention of burn injuries. Measuring of self reported behavior change is also suspect because of the well documented tendency to over report use of prevention strategies such as seat belts. ${ }^{13}$

Another possible way to evaluate strategies is to examine changes in proxies for injuries, that is injury prevention behaviors. We know that the use of seat belts ${ }^{14}$ and bike helmets ${ }^{15}$ are effective prevention strategies. Thus, increases in the use of these devices, which can be much 
Table 6 Direct observations of seatbelt and bicycle helmet use for Think First evaluation; results are number observed ( $\%$ positive)

\begin{tabular}{|c|c|c|c|c|c|}
\hline & $\begin{array}{l}\text { Before } \\
\text { assembly }\end{array}$ & $\begin{array}{l}2 \text { weeks } \\
\text { after } \\
\text { assembly }\end{array}$ & $p$ Value $e^{\star}$ & $\begin{array}{l}3 \text { months } \\
\text { after } \\
\text { assembly }\end{array}$ & p Value \\
\hline \multicolumn{6}{|l|}{$\begin{array}{l}\text { Junior high school } \\
\text { (1 school) }\end{array}$} \\
\hline $\begin{array}{l}\text { Seat belt use } \\
\text { Helmet use } \\
\text { High school } \\
\text { (1 school) }\end{array}$ & $\begin{array}{c}52(31) \\
9(0)\end{array}$ & $\begin{array}{l}47(36) \\
8(0)\end{array}$ & $\begin{array}{l}0.03 \\
\text { NS }\end{array}$ & $\begin{array}{c}33(27) \\
3(0)\end{array}$ & $\begin{array}{l}<0.05 \\
\text { NS }\end{array}$ \\
\hline $\begin{array}{l}\text { Seat belt use } \\
\text { Helmet use } \\
\text { Control school } \dagger \\
\text { (1 school) }\end{array}$ & $\begin{array}{l}148(57) \\
\quad 1(100)\end{array}$ & $\begin{array}{c}139(45) \\
1(0)\end{array}$ & $\begin{array}{l}0.03 \\
\text { NS }\end{array}$ & $\begin{array}{c}33(27) \\
3(0)\end{array}$ & $\begin{array}{l}<0.05 \\
\text { NS }\end{array}$ \\
\hline $\begin{array}{l}\text { Seat belt use } \\
\text { Helmet use }\end{array}$ & $52(31)$ & $\begin{array}{l}45(29) \\
0\end{array}$ & NS & & \\
\hline
\end{tabular}

vals were 2 weeks before and 1 day before the Think First assembly.

more readily and frequently observed than changes in actual injury rates, can be logically related to prevention of injuries. This strategy has been widely used for the evaluation of seat belt ${ }^{16}$ and bike helmet ${ }^{17}$ promotion programs.

In this evaluation of the Think First program, we attempted to examine changes in attitudes, knowledge, and self reported behavior as well as changes in seat belt and helmet use. The results indicate a small impact on knowledge, and essentially no impact on attitudes or self reported behaviors. While the sample size was relatively small, the study was large enough to detect a difference of one correct question in the summary scores for knowledge and attitudes. There did not appear to be any ceiling effect on the knowledge questionnaire as only about two thirds of students answered the questions correctly. Our ability to detect changes in behavior were more limited, as few of the students bicycled to school and relatively small numbers of students were observed riding in cars. Nevertheless, there did not appear to be any consistent trend in seat belt use after the Think First program.

These findings are also similar to prior evaluations of the Think First program. An evaluation of a program in Oregon showed changes in knowledge among middle and high school students but no change in self reported seat belt or helmet use. ${ }^{18}$ Other evaluations have also documented changes in knowledge and attitudes, but none have actually found changes in behavior. ${ }^{19-21}$

There are a number of potential limitations to the study. The schools were not selected at random, but represented schools in which there were sizable student bodies and in which the principal of the school and the superintendent of the district were willing to have both the Think First assembly and the evaluation. We were only able to get one school willing to serve as a control to test the reactivity of the questionnaire, other principals felt that serving as a control was a waste of students' and teachers' time. In order to get the control school cooperation, we nevertheless had to shorten the questionnaire to include only selected items. Both the selection of the control school and the use of a shortened questionnaire could have introduced bias. However, there did not appear to be any changes in responses on the question- naire between first and second surveys, leading us to believe that the bias was minimal.

The number of observations of bike helmet use were far less than expected, severely limiting our ability to comment on the impact of the program on helmet use. While the number of observations of seat belt use was also low, there was no consistent trend indicating impact of the program on use.

We were not able to collect socioeconomic information about the children or their families. However, the study included urban, suburban, and rural schools, and a variety of ethnic groups. It is thus unlikely that the limited impact of the Think First program was due to a large number of children at either end of the socioeconomic spectrum.

The three month assessment was limited to only three schools. However, the lack of any consistent effect on changes in knowledge, self reported or observed behavior at two weeks after the assembly makes it unlikely that any meaningful effect of the program was missed in the three month evaluation.

These results should not be unexpected. The program was a one time intervention that covered a wide variety of topics such as seat belt use, bike helmet use, diving behavior, drinking while driving, and general risk taking. Most injury prevention strategies that have tackled broad issues of injury have failed to produce an impact. ${ }^{1012}$ Likewise programs that have relied solely on education, even when well done, have often between unsuccessful. ${ }^{122}$ Those injury prevention strategies that have produced the best results have used a combination of education with other approaches such as legislation, regulation, or lowering barriers to implementation. These include child seat restraints, ${ }^{23}$ poisoning prevention, ${ }^{24}$ motorcycle helmet use legislation, ${ }^{25}$ and bicycle helmets. ${ }^{17}$ In addition, successful programs have usually been narrowly focused on single issues and have offered specific interventions.

The age group targeted by this program is one where it is very difficult to achieve behaviour change. This population has among the lowest rates of seat belt use despite years of education and legislation. ${ }^{26}$ Risk taking has been postulated by some to be a normative behavior for adolescents and thus very difficult to change by any program. ${ }^{27}$

Prevention of injuries to this age group must therefore rely heavily on passive strategies combined with regulation and legislation in addition to education. The use of air bags, mandatory helmet legislation, decreased access to firearms, and restriction of alcohol availability will likely have a greater impact on traumatic brain injury and spinal cord injury than even more extensive, but isolated, educational efforts such as Think First.

Funded by grant No R49/CR002570 from the Centers for Disease Control and Prevention.

1 Kraus JF, Rock A, Hemyari P. Brain injuries among infants, children, adolescents and young adults. Am $\mathcal{F}$ Dis Child 1990; 144: 684-91.

2 Kalsbeek WD, McLaurin RL, Harris BSH, Miller JD. The national head and spinal cord injury survey: major findings. $\mathcal{F}$ Neurosurg 1980; 53 (suppl): 519-31. 
3 Fay GC, Jaffe KM, Polissar NL, Liao S, Rivara JB, Martin KM. Outcome of pediatric traumatic brain injury at three years: a cohort study. Arch Phys Med Rehabil 1994; 75: 733-41.

4 Rivara JB. Family functioning following pediatric traumatic brain injury. Pediatr Ann 1994; 23: 38-44.

5 Max W, MacKenzie EJ, Rice DP. Head injuries: costs and consequences. Fournal of Head Trauma and Rehabilitation 1991; 6: 76-91.

6 Rice DP, MacKenzie EJ and Associates. Cost of injuries in the United States. A report to congress. San Francisco, CA: United States. A report to congress. San Francisco, CA:
Institute for Health and Aging, University of California and Injury Prevention Center, The Johns Hopkins and Injury Prevent

7 Miller L. Instruction guide for conducting the national head and spinal cord injury prevention program of the American Association of Neurological Surgeons and Congress of Neurological Surgeons. 2nd Ed. Park Ridge, IL: AANS/ CNS, 1989.

8 Eyster F. Comments on evaluation of a program to prevent head and spinal cord injuries. Neurosurgery 1992; 31: 561-2.

9 Rosenstock IM. Why people use health services. Millbank Memorial Fund Quarterly 1966; 4: 94-127.

10 Pless IB, Arsenault L. The role of health education in the prevention of injuries to children. Fournal of Social Issues 1987; 43: 87-103.

11 Rivara FP, Wolf ME. Injury research: where should we go from here. Pediatrics 1989; 84: 180-1.

12 McLoughlin E, Vince CJ, Lee Am, et al. Project Burn Prevention: outcome and implications. Am $\mathcal{f}$ Public Health 1982; 72: 241-7.

13 Centers for Disease Control. Comparison of observed and self-reported seat belt use rates - US. MMWR 1988; 37: $549-51$

14 Evans $L$. The effectiveness of safety belts in preventing fatalities. Accid Anal Prev 1986; 18: 229-41.

15 Thompson RS, Rivara FP, Thompson DC. A case control study of the effectiveness of bicycle safety helmets. $N$ Engl f Med 1989; 320: 1361-7.
16 Williams AF, Lund AK. Seat belt use laws and occupant crash protection in the US. Am $\mathcal{F}$ Public Health 1986; 76: 1438-42.

17 Di Guiseppi DG, Rivara FP, Koepsell TD, Polissar L. Bicycle helmet use by children: evaluation of a community-wide helmet campaign. $\mathcal{F} A M A$ 1989; 262: 2256-61.

18 Avolio AEC, Ramsey FL, Neuwelt EA. Evaluation of a program to prevent head and spinal cord injuries: a
comparison of middle school and high school. Neurosurgery 1992; 31: 557-62.

19 Lechman BC, Bonwich EB. Evaluation of an education program for spinal cord injury prevention: some preliminary findings. Science Digest $1981 ; 3: 27-34$

20 Shaw LR, McMahon BT, Bruce JH. The Flordia approach to spinal cord injury prevention. Rehabilitation Literature 1984; 45: 85-9.

21 Eyster EF, Watts C. An update of the national head and spinal cord injury prevention program of the American Association of Neurological Surgeons and the Congress of Neurological Surgeons: Think First. Clin Neurosurg 1992; 38: 252-60.

22 Roberston LS. Injuries: causes, control strategies and public policy. Lexington, MA: Lexington Books, 1983.

23 Partyka SC. Lives saved by child restraints from 1982 through 1987. Washington, DC: National Highway Traffic Safety Administration, 1989.

24 Walton WW. An evaluation of the poison prevention packaging act. Pediatrics 1982; 69: 363-70.

25 McSwain NE, Belles A. Motorcycle helmets - medical costs and the law. F Trauma 1990; 30: 1189-97.

26 Hingson R, Howland J, Schiavone T, Damiata M. The Massachusetts saving lives program. Fournal of Traffic Medicine 1991; 18: 123-32. 27 Elliott DS. Health-enhancing and health-compromising
lifestyle. In: Millstein SG, Petersen AC, Nightingale EO, eds. Promoting the health of adolescents. New Directions for the twenty-first century. New York: Oxford University Press, 1993: 119-45. 